MALLOMO: Journal of Community Service

https://jurnal.umsrappang.ac.id/mallomo/index

Vol 1, No 2, Juni 2021, pp 56-63

\title{
Pemberdayaan Masyarakat: Peningkatan Usaha Desa Berbasis Keunggulan Lokal Di Desa Santan Tengah Kabupaten Kutai Kartanegara
}

\author{
Budiman $^{1^{*}}$, Anwar Alaydrus ${ }^{2}$, Jumansyah ${ }^{3}$, Tengku Imam Syarifuddin ${ }^{4}$, Anita Wahyuni ${ }^{5}$ \\ 1,2, 3, 4, 5 IImu Pemerintahan, Fakultas IImu Sosial dan IImu Politik, Universitas Mulawarman \\ Email: budiman@fisip.unmul.ac.id
}

Abstract. Increasing the opportunities and potentials of village businesses based on local excellence aims to optimize the development of Santan Tengah Village by exploring the potential of the village of Santan Tengah which is not well known by the village government and which is of interest to the community, so that in the future Santan Tengah village can become an independent village through local excellence. The initial phase of the activity, an initial discussion will be carried out with the village government to get an overview of the village of Santan Tengah, then a survey of village potential will be carried out in cooperation with the village authorities. The next stage of the survey results carried out discussions with the village and several community representatives to determine the priority scale for village excellence that could have a significant impact on future village development through village efforts. Then it is socialized to the community in order to create awareness of the superiority of the village which can be an opportunity and potential for the economic independence of the village community. The output of this activity is in the form of recommendations for strategic planning to increase village business, publication of writings on the creation of independent villages and village business priority plans that will be disseminated online and offline on an ongoing basis so that the community can be active in supporting the plan to increase the village business of Santan Tengah. From this community service activity, it provides benefits to the village government and the community in Santanh Tengah village in the form of ease in planning strategic planning alternatives to increase local excellence-based village businesses, namely the coconut oil business and the business of supplying palm oil fresh fruit bunches 
(FFB) produced by community plantations to companies. palm fruit processor.

Abstrak. Meningkatkan peluang dan potensi usaha desa berbasis keunggulan lokal bertujuan untuk mengoptimalkan pembangunan Desa Santan Tengah dengan menggali potensi desa yang kurang diketahui oleh pemerintah desa dan diminati oleh masyarakat, sehingga ke depan desa Santan Tengah dapat menjadi desa mandiri melalui keunggulan lokal. Tahap awal kegiatan, akan dilakukan pembahasan awal dengan pihak pemerintah desa untuk mendapatkan gambaran umum terkait desa Santan Tengah, selanjutnya akan dilakukan survei potensi desa dengan kerja sama pihak desa. Tahap selanjutnya dari hasil survei tersebut dilakukan pembahasan bersama pihak desa dan beberapa perwakilan masyarakat untuk menentukan skala prioritas keunggulan desa yang dapat memberikan dampak signifikan terhadap pembangunan desa kedepan melalui usaha desa. Kemudian disosialisasikan kepada masyarakat dalam rangka meciptakan kesadaran akan keunggulan desa yang dapat menjadi peluang dan potensi kemandirian ekonomi masyarakat desa.

Luaran dari kegiatan ini berupa rekomendasi perencanaan strategis peningkatan uasaha desa, publikasi tulisan penciptaan desa madiri dan rencana prioritas usaha desa akan isosialisasikan secara daring dan luring secara berkelanjutan agar masayarakat dapat aktif dalam mendukung rencana peningkatan usaha desa Santan Tengah. Dari kagiatan pengabdian masyarakat ini memberikan manfaat kepada pemerintah desa dan masyarakat di desa Santanh Tengah berupa kemudahan dalam merencanakan alternatif perencanan strategis peningkatan usaha desa berbasis keunggulan lokal yaitu usaha minyak kelapa dan usaha pemasokan tandan buah segar (TBS) kelapa sawit hasil produksi perkebunan masyarakat kepada perusahaan pengelolah buah sawit.

\section{Keywords:}

Community

empowerment, Village

bisniss, local excellent.

Kata Kunci:

Pemberdayaan

masyarakat, usaha

desa, keunggulan

desa.
Coresponden author:

Email: budiman@fisip.unmul.ac.id

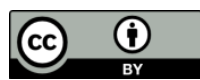

artikel dengan akses terbuka di bawah lisensi CC BY -4.0

\section{PENDAHULUAN}

Penguatan eksistensi desa melalui kehadiran Undang-Undang Nomor 6 Tahun 2014 Tentang Desa telah memberikan ruang gerak yang labih luas untuk melakukan pembangunan multidimensiona, artinya bahwa desa saat ini ditempatkan sebagai sentra pembangunan nasional (Ridzal dan Hasan, 2020). Dengan demikian dalam pelaksanaan pembangunan desa dibutuhkan sebuah 


\section{8 | MALLOMO: Journal of Community Service}

perencanaan yang strategis yang dapat disesuaikan dengan potensi atau keunggulan desa yang dapat menjamin keberlanjutan pembangunan desa (Nugroho dkk, 2014).

Potensi desa adalah berbagai sumber alam (fisik) dan sumber manusia (non fisik) yang tersimpan dan ditemukan di suatu desa, dan diharapkan kelangsungan dan pertumbuhan desa dapat memperoleh manfaat dari potensi tersebut. Selanjutnya Soleh (2017) mengklasifikasikan potensi desa menjadi potensi fisik dan non fisik. Potensi fisik terdiri dari, pertama tanah dalam artian ertambangan dan sumber daya mineral, sumber mata pencaharian tanaman, makanan dan papan. Kedua air dalam artian dalam hal sumber air, kondisi irigasi dan sistem pengairan, kesatuan dan kebutuhan sehari-hari. Ketiga iklim dimana peranannya sangat penting bagi desa yang bersifat agraris. Keempat hewan ternak sebagai sumber energi, pangan dan pendapatan, dan terakhir manusia sebagai sumber tenaga kerja potensial, baik sebagai petani lahan maupun sebagai produsen pertanian. Selanjutnya Potensi non fisik terbagi menjadi tiga yaitu masyarakat desa, lembaga-lembaga desa, dan aparatur atau pamong desa. Masyarakat desa yang hidup berdasarkan gotong royong dan dapat merupakan suatu kekuatan berproduksi dan kekuatan membangun atas dasar kerja sama dan saling pengertian. Selanjutnya lembaga-lembaga desa merupakan lembaga sosial, pendidikan, dan organisasi-organisasi sosial yang dapat memberikan bantuan sosial dan bimbingan terhadap masyarakat. Terakhir aparatur atau pamong desa berfungsi untuk menjaga ketertiban dan keamanan demi kelancaran jalannya pemerintahan desa.

Desa Santan tengah terletak di Kecamatan Marangkayu, Kabupaten Kutai Kartanegara. Desa Santan Tengah terbagi atas empat dusun yaitu Dusun Handil Tiga, Handil Dua, Handil Mico, dan Dusun Kampung Mesjid. Sihingga total jiwa dari akumulasi semua Dusun adalah 2.615 jiwa. Sistem pengolahan tanah di Desa Santan tengah belum mencerminkan pola tanam/pengolahan lahan pertanian secara baik, sehingga tingkat produktifitas/hasil yang dicapai di sektor pertanian belum optimal. Secara umum masyarakat di Desa Santan Tengah merupakan masyarakat dengan etnis bugis. Potensi perkebunan, pertanian, sangat didukung dengan kondisi gografis, dimana desa Santan Tengah memiliki tanah yang subur karena masih banyak lahan yang baru dibuka dari sebelumnya hutan dan terdapat sungai yang cukup panjang yang melewati dusun Kampung Mesjid.

Usaha di bidang pertanian (tanaman pangan, hortikultura, perkebunan dan peternakan) merupakan kegiatan yang prospektif untuk dikembangkan, mengingat bahwa Desa Santan Tengah merupakan desa yang memiliki potensi perkebunan khususnya komoditas kelapa dan kelapa sawit yang menjanjikan bagi peningkatan kesejahteraan masyarakat serta pengelolaan hasil perkebunan kelapa dan kelapa sawit yang dapat meningkatkan usaha desa.

Namun permasalahan kemudian adalah rendahnya perencanaan strategis Usah desa dan keterbatasan sumber daya pemerintah desa Santan tengah dalam mengelola keunggulan desa. Selanjutnya rendahnya kesadaran masyarakat dalam memahami nilai-nilai ekonomis yang dapat dihasilkan jika keunggulan desa dikelola secara berkelanjutan dan terintegrasi dengan badan usaha milik desa, karena berdasarkan apa yang disampaikan oleh Presiden Republik Indonesia Jokowidodo bahwa ada beberapa faktor kunci dalam pertumbuhan dan pemerataan ekonomi desa yaitu mendongkrak perekonomian desa melalui peningkatan tata kelola usaha desa, meningkatkan pendapatan asli desa, serta optimalisasi potensi desa sesuai kebutuhan masyarakat (Prasetyo dkk, 
2018). Proses pemetaan peluang usaha desa yang secara masif juga menjadi fakto yang sangat berpengaruh dalam pengelolaan potensi desa. Tentu sangat dibutuhkan gerakan-gerakan sistematis untuk memulai pemetaan-pemetaan potensi keunggulan lokal desa yang dapat kembali menyadarkan dan memberikan pengaruh positif terhadap pentingnya mengoptimalkan keunggulan desa yang sebenarnya memiliki nilai ekonomis yang tinggi. Oleh sebab itu sangat dibutuhkan dorongan dari luar temasuk dalam bentuk pelibatan universitas atau akademis sebagai bentuk pengabdian kepada masyarakat untuk terjun langsung memberikan penyuluhan maupun bentuk nyata dalam memberikan kesadaran akan pentingnya mengoptimalkan keunggulan desa dalam meningkatkan usaha desa untuk membangun desa mandiri.

Luaran dari kegiatan ini berupa, rekomendasi peningkatan usaha desa, tulisan terkait pembangunan desa madiri melalui peningkatan usaha desa berdasarkan keunggulan lokal dan rencana strategis usaha desa Santan Tengah yang akan disosialisasikan secara berkelanjutan kepada masyarakat setempat secara daring dan luring.

\section{Metode}

Metode dimulai dengan memberikan pemahaman terkait dengan pentingnya mengoptimalkan keunngulan desa, setelah itu dilakukan survei keunggulan desa. Hasil survei akan dibahas bersama pihak desa serta beberapa perwakilan masyarakat dilaksanakan mengunakan metode focus group discussion (FGD). FGD juga dikenal sebagai metode dan teknik pengumpulan data kualitatif dengan melakukan wawancara kelompok. FGD dapat digambarkan sebagai metode dan teknik pengumpulan data kualitatif untuk mendapatkan pemahaman yang lebih tepat dimana sekelompok orang yang menangani suatu masalah atau subjek diarahkan oleh fasilitator atau moderator (Indrizal, 2014). FGD tersebut membahas terkait dengan skala prioritas keunggulan desa yang akan di ditingkatkan menjadi usaha desa. Pelaksanaan FGD dilaksanakan secara daring dan luring. Hasil tersebut selanjutnya di sosialisasikan kepada masyarakat terkait rencana prioritas pemerintah desa dalam mengembangkan keunggulan desa. Pelaksanaan kegiatan melibatkan pihak pemerintahan desa (Bumdes) dan masyarakat setempat. Perlu digaris disampaikan bahwa dalam pelaksanaan kegiatan pengabdian ini dilakukan melalui daring dan luring, mengingat bahwa kegiatan pengabdian ini dilakukan di saat pandemi Covid-19.

\section{A. Waktu dan Lokasi Pelaksanaan Kegiatan}

Kegiatan pengabdian masyarakat yang laksanakan selama 3 bulan Juli-September 2020.

Pelaksanaan pengabdian dilakukan secara daring dan luring.

\section{B. Tahapan Kegiatan}

Tahapan kegiatan yang dilakukan dalam kegiatan ini dilakukan dengan cara berikut ini.

1. Tahap awal kegiatan, akan dilakukan pembahasan awal dengan pihak pemerintah desa untuk mendapatkan gambaran umum terkait desa Santan Tengah.

2. Dilakukan survei potensi desa dengan kerja sama pihak desa.

3. Hasil survei tersebut dilakukan pembahasan bersama pihak desa dan beberapa perwakilan masyarakat untuk menentukan skala prioritas keunggulan desa yang dapat memberikan dampak signifikan terhadap pembangunan desa kedepan melalui usaha desa.

4. Sosialisasikan kepada masyarakat dalam rangka meciptakan kesadaran akan keunggulan desa yang dapat menjadi peluang dan potensi kemandirian ekonomi masyarakat desa

\section{Hasil Dan Pembahasan}

Kegiatan pengabdian masyarakat diawali dengan pertemuan dengan tim pengabdian untuk membahas agenda kegiatan pengabdian yang akan dilaksanakan di desa Santan Tengah. Sehinggan sebelum tim pengandian kelapangan, untuk menjaga intensitas petemuan dengan pihak pemerintah dalam rangka tetap meperhatikan protokol Covid-19, terlebih dahulu tim pengabdian 
berkomunikasi dengan pemerintah desa Santan Tengah melalui daring. Dalam komunikasi tersebut tim pengabdian menemukan sekilas gambaran umum terkait desa Santan Tengah bahwa desa tersebut pada mulanya merupakan desa yang didominasi dengan perkebunan kelapa dan memiliki aliran sungai yang strategis sebagai salah satu mata pencaharian masyarakat setempat. Sungai tersebut melintasi sala satu dusun yang menjadi pusat peradaban masyarakat Santan Tenganh yaitu Dusun Kampung Masjid. Namun pada tahun 90-an masyarakat desa Santan Tengah mengalami perubahan arah perekonomian yang sangat drastis seiring dengan kebakaran lahan perkebunan yang melanda di desa Santan Tengah serta seiring mulai masuknya perusahaan pertambangan batu bara. Masyarakat desa Santan Tengah Mulai beralih untuk bekerja pada perusahaan batu bara yang ada di sekitar desa Santan Tengah.



Gambar 1. Sungai Santan Tengah

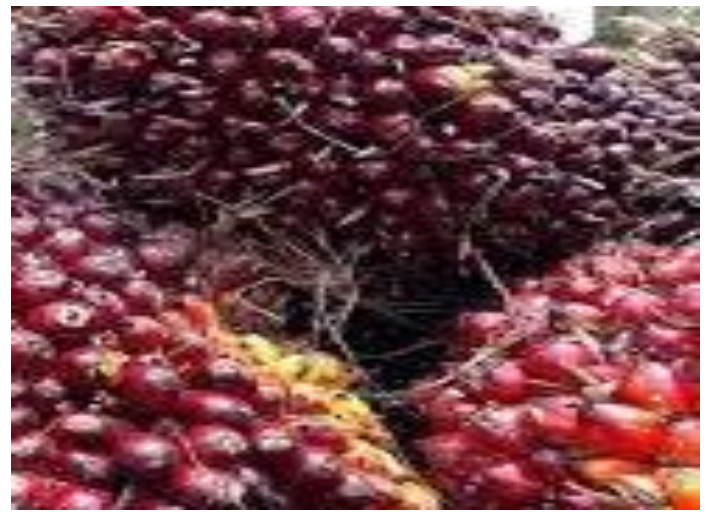

Gambar 3. Hasil Perkebunan Kelapa Sawit

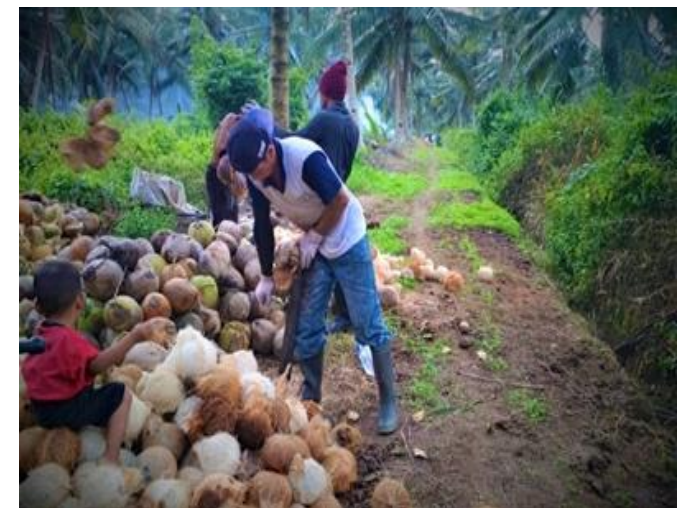

Gambar 2. Hasil Perkebunan Kelapa

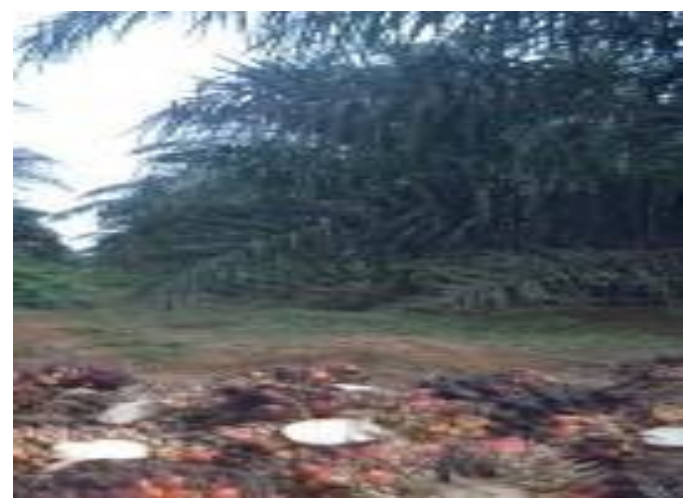

Gambar 4. Hasil Perkebunan Kelapa Sawit

Berdasarkan agenda tim pengabdian yang telah ditetapkan maka selanjutnya adalah tim pengabdian melakukan survei langsung kelapangan untuk menemukan potensi keunggulan lokal yang dapat dikembangkan menjadi usaha desa dalam rangka meningkatkan kemandirian pembangunan desa Santan tengah. Dari survei tersebut tim pengabdiang menemukan beberapa keunggulang lokal yang dapat ditingkatkan menjadi usaha desa yaitu kaunggulan perkebunan kelapa sawit, kelapa, dan terdapat aliran sungai yang dapat menjadi tempat budidaya ikan tawar dalam bentuk keramba. 
Perkebunan kelapa sawit mendominasi pada setiap dusun yang ada di desa Santan Tengah yaitu dusun handil mico, dusun kampung masjid, dusun handil dua, dan dusun handil tiga serta kelapa sawit mulai masuk di desa santan tengah sekitas tahun 2006 Sedangkan pada perkebunan kelapa saat ini hanya mejadi komoditas kedua setelah kelapa sawit dan hanya dusun tertentu yang masi memiliki perkebunan kelapa yaitu dusun handil tiga. Selanjutnya keunggulan desa lainnya yaitu adanya aliran sungai yang terdapat di dusun kampung Masjid yang dapat ditingkatkan menjadi usaha desa melalui budidaya ikan tawar dalam bentuk keramba. Namun untuk keunggulan sungai yang dimiliki oleh desa Santan Tengah tepatnya di dusun kampung masjid, berdasarkan survei tim pengabdian ditemukan sebuah masalah yang terjadi pada sungai tersebut dimana sungai tersebut telah tercemari oleh limbah pertambangan batubara PT. Indominco Mandiri yang beraktivitas di hulu sungai yang berdampak buruk pada kualitas air sungai menjadi keruh, bercampur lumpur dan menagalami pendangkalan serta kerap menimbulkan banjir dimusim hujan.

Kemudian temuan tim pengabdian dari survei lapangan selanjutnya ditemukan keunggukan kelapa yang masi menjadi komoditas kedua dari kelapa sawit yang dapat diolah menjadi minyak makan melalui cara manual (Metode Fermentasi) yang tidak memerlukan biaya tinggi dan tentunya memiliki nilai ekonomi tinggi mengingat bahwa minyak kelapa semakin sulit untuk diperoleh dan memiliki kandungan yang dapat manambah cita rasa makanan dibandingkan dengan minyak kelapa sawit yang slama ini banyak dikomsumsi oleh masyarakat pada umumnya. Disamping itu minyak kelapa tidak hanya menjadi minyak makan namun juga dapat menjadi bahan altenatif dalam kesehatan diantaranya sebagai minyak urut berdasarkan berbagai informasi yang dihimpun oleh tim pengabdian.

Selanjutnya dalam survei yang dilakukan oleh tim pengabdian juga menemukan komoditas keunggulan desa Santan Tengah yaitu perkebunan kelapa sawit yang saat ini menjadi komoditas utama dalam meningkatkan perekonomian masyarakat di Desa Santan Tengah. Dalam usaha peningkatan usaha desa komoditas kelapa sawit tersebut dapat menjadi usaha strategis desa untuk meningkatkan kemandirian pembangunan desa. Dengan keunggulan desa tersebut usaha desa santan tengah dapat ditingkatkan malalui usaha pemasokan tandan buah segar (TBS) dengan membeli hasil produksi perkebunan kelapa sawit masyarakat desa Santan Tengah. Kemudian disalurkan ke sejumlah perusahaan pengelolaan buah kelapa sawit yang telah bekerja sama dengan pemerintah desa Santan Tengah.



Gambar. 5 Pelaksanaan FGD

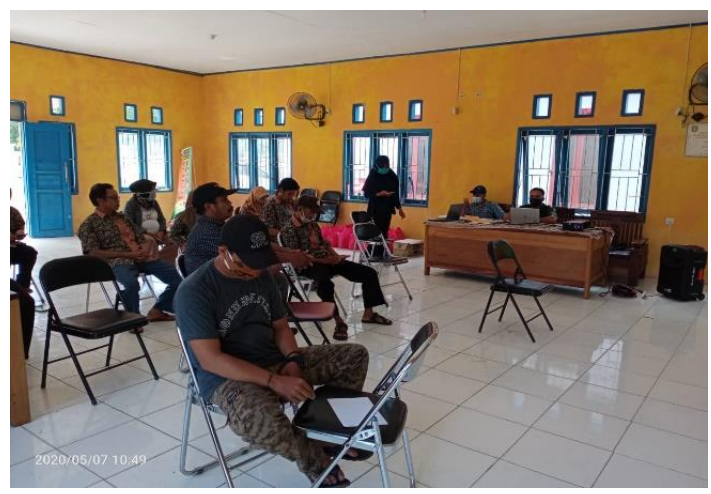

Gambar. 6 Pelaksanaan FGD 


\section{2 | MALLOMO: Journal of Community Service}

Setelah dilakukan survei dan ditemukan beberapa keunggulan desa sebagaimana yang telah disebutkan diatas, selanjudnya tim pengabdian melakukan FGD bersama pemerintah desa dan beberapa masyarakat untuk membahas keunggulan desa yang dianggap oleh tim pengabdian dapat ditingkatkan menjadi usaha desa Santan Tengah yaitu minyak kelapa dan pembelian hasil produksi perkebunan kelapa sawit melalui Bumdes. Dari pembahasan menghasilkan beberapa poin strategis dalam upaya peningkatan usaha desa Santan Tengah berbasis keunggulan lokal ke depan yaitu:

1. Setelah tim pengabdian menjelaskan terkait hasil dari survei keunggulan desa Santan Tengah. Pihak pemerintah desa sangat terbantu dalam melakukan alternatif-alternatif perencanaan peningkatan usaha desa dalam mewujudkan pembangunan desa mandiri.

2. Ditemukan sebuah alternatif pemerintah desa untuk memprioritaskan peningkatan usaha desa dengan peningkatan pengelolaan minyak kelapa dan usaha pemasokan tandan buah segar (TBS) kelapa sawit hasil produksi perkebunan masyarakat kepada perusahaan pengelolah buah sawit.

3. Dalam pertemuan ini juga berdampak pada pemahamaan masyarakat setampat untuk terlibat langsung dalam mendukung rencana prioritas usaha desa kedepan.

4. Hasil dari pertemuan terkait peningkatan usaha desa bersama dengan pemerintah dan masyarakat desa santan tengah juga menhasilkan sebuah pemahaman bahwa peningkatan rencana usaha desa melalu kegiatan pemasokan tandan buah segar (TBS) kelapa sawit hasil produksi perkebunan masyarakat tidak hanya meningkatkan perekonomia desa tetapi juga dapat mengatasi kenakalan penengkulak yang kerap mebeli buah sawit masyarakat dengan harga murah dengan alasan banjir buah di pabrik pengolahan buah sawit.

Dari hasil pertemuan bersama pemerintah desa dan beberapa perwakilan masyarakat di Desa Santan tengah, tim penngabdian selanjutnya melakukan sosialisasi kepada masyarakat terkait dengan rencana strategis peningkatan usaha desa Santan Tengah kedepan dan kegiatan ini dilakukan dengan cara daring dan luring mengingat kagiatan ini dilakukan di tengah Pandemi Covid19. Dalam sosialisasi tersebut tim pengabdian masih memiliki keterbatasan untuk lebih intens bertemu masyarakat dikarenakan dengan adanya protokol kesehatan yang harus diutamakan. Namun sosialisasi tersebut akan berlanjut baik secara daring maupun luring. Secara daring tim Pengabdian telah tergabung dalam sebuah Group WhatsApp yang dalamnya terdiri dari masyarakat dan pemerintah desa secara langsug sebagai pengelola Group WhatsApp tersebut.

\section{Simpulan Dan Saran}

Kegiatan pengabdian kepada masyarakat di desa Santan Tengah telah terselenggara sesuai dengan target tim pengabdian yang telah direncanakan sebelumnya. Meskipun dilaksanakan ditengah pandemi Covid-19, namum tidak mengurangi substansi kegiatan pengabdian masyarakat yang laksanakan selama 3 bulan Juli-September 2020. Hal tersebut ditandai dengan antuasias pihak pemerintah desa dan masyarakat untuk mendukung pengabdian ini sehingga dari pengabdian ini mampu memberikan sebuah hasil dalam menciptakan prioritas peningkatan usaha desa Santan Tengah berbasis keunggulan lokal dalam mewujudkan pembangunan desa mandiri, yang kemudian ditindak lanjuti oleh pemerintah desa Santan Tengah melalui prioritas perencanaan strategis usaha desa kedepan dengan usaha pengelolaan minyak kelapa dan kegiatan pemasokan tandan buah 
segar (TBS) yang dikelolah oleh badan usaha milik desa. Karena saat ini usaha desa Santan tengah masih hanya berfokus pada pengelolaan air bersih.

\section{Daftar Rujukan}

Indrizal, E. (2014). Diskusi kelompok terarah. Jurnal Antropologi: Isu-Isu Sosial Budaya, 16(1), 7582.

Nugroho, D. O., Hariani, D., \& Lestari, H. (2014). Perencanaan Strategis Pembangunan Desa Di Desa Pingit Kecamatan Rakit Kabupaten Banjarnegara. Journal of Public Policy and Management Review, 3(4), 190-201.

Prasetyo, P. S. dkk. 2018. Inovasi Pengembangan Ekonomi Desa Berbasis Potensi Lokal Desa. Jakarta. Friedrich Ebert Stiftung (FES).

Ridzal, Nining Asniar \& Hasan, Waode Adriani. 2020. Eksistensi Badan Usaha Milik Desa (BUMDes) Sebagai Penggerak Perekonomian Desa. Jurnal Pengabdian Kepada Masyarakat: Mebangun Negeri. 4 (1): 98-106.

Soleh, A. (2017). Strategi pengembangan potensi desa. Jurnal Sungkai, 5(1), 32-52.

Undang-Undang Nomor 6 Tahun 2014 Tentang Desa. 